\title{
LRRC19 wt Allele
}

National Cancer Institute

\section{Source}

National Cancer Institute. LRRC19 wt Allele. NCI Thesaurus. Code C104618.

Human LRRC19 wild-type allele is located in the vicinity of 9p21.2 and is approximately 13 $\mathrm{kb}$ in length. This allele, which encodes leucine-rich repeat-containing protein 19, may be involved in inducing innate immune responses in kidney and other tissues. 